\title{
Evaluation of the performance of the first automatic milking system for buffaloes
}

\author{
M. Caria, ${ }^{*}$ F. M. Tangorra, $\dagger^{1}$ S. Leonardi, $\dagger$ V. Bronzo, $\dagger$ L. Murgia, ${ }^{*}$ and A. Pazzona* \\ *Dipartimento di Agraria, Sezione di Ingegneria del territorio, Università degli Studi di Sassari, 07100 Sassari, Italy \\ †Dipartimento di Scienze Veterinarie per la Salute, la Produzione Animale e la Sicurezza Alimentare (VESPA), Università degli Studi di Milano, \\ 20133 Milano, Italy
}

\section{ABSTRACT}

The objective of this study was to evaluate the response of buffaloes to automatic milking, examining the relationships between milking interval, milk production, and milking time for this species. A total of 7,550 milking records from an average of 40 buffaloes milked by an automatic milking system (AMS) were analyzed during a 3-mo experimental period at a commercial farm with Italian Mediterranean buffaloes in southern Italy. Date and time of animal identification, milk yield, milking duration, milking interval, and average milk flow rate were determined for each milking. The results were also used to predict the maximum number of milkings per day and the optimal number of buffaloes per AMS for different levels of milk production. The average interval period between 2 consecutive milkings was $10.3 \mathrm{~h}$ [standard deviation (SD) 3.3]. Overall, 3.4 and $25.7 \%$ of the milkings had an interval of $\leq 6 \mathrm{~h}$ or $>12 \mathrm{~h}$, respectively. Milking duration averaged 8.3 min per buffalo per milking (SD 2.7). The average milk flow rate was $1.3 \mathrm{~kg} / \mathrm{min}(\mathrm{SD} 0.5$ ) at a milk yield of $2.8 \mathrm{~kg}$ per milking (SD 1.4). Assuming that the milking station is occupied $80 \%$ of the time, the number of milkings ranged from 136 to 152 per day and the optimal number of buffaloes per AMS ranged from 59 to 66 when the production level increased from 2 to $5 \mathrm{~kg}$ of milk per milking. Automatic milking systems are suitable for buffalo, opening new options for the management of dairy buffalo farms.

Key words: automatic milking system, dairy buffalo, milking performance

\section{INTRODUCTION}

Automatic milking systems (AMS) were a revolutionary innovation in dairy cow farming and can be seen not only as replacements for milking parlors but

Received August 18, 2013.

Accepted November 10, 2013.

${ }^{1}$ Corresponding author: francesco.tangorra@unimi.it also as a new way of managing dairy farms. The first AMS were installed in the Netherlands in 1992, even though interest in fully automated milking began in the 1970s. This interest was initially due to increasing costs of labor, land, buildings, and machinery, combined with decreasing milk prices (de Koning et al., 2002; de Koning and Rodenburg, 2004). By 2009, about 8,000 farms had adopted AMS (Svennersten-Sjaunja and Pettersson, 2008; de Koning, 2010) and AMS can now be considered a well-established technology. About $90 \%$ of AMS are installed in dairy farms in northern Europe, whereas the remainder are located in Canada (9\%) and the United States (1\%) (de Koning, 2010). The slow adoption of AMS in the United States may be due to farmer uncertainty about using the new technology; the lack of readily available support services in the event of mechanical or technical problems; the availability of less-expensive labor compared with other countries; and a higher proportion of large farms, where installing AMS may be less economically advantageous than in the smaller farms of northern Europe (Rotz et al., 2003; Jacobs and Siegford, 2012).

The main factors promoting the adoption of AMS for dairy cows are better organization of labor, increased milk yields, and improved animal behavior (Hogeveen et al., 2001). Automatic milking systems reduce the heavy workload of milking and enable milking frequency to be controlled on an individual cow basis, according to her production level or stage of lactation, without incurring extra labor costs (Hogeveen et al., 2001; Svennersten-Sjaunja and Pettersson, 2008; Jacobs and Siegford, 2012). All else being equal, cows milked more frequently throughout a lactation usually produce greater amounts of milk compared with cows milked twice a day (Stelwagen et al., 2013; Wright et al., 2013). Some researchers have observed an increase in milk production of up to $12 \%$ for cows milked more than twice a day in AMS compared with cows milked twice a day in conventional milking systems (de Koning et al., 2002; Wagner-Storch and Palmer, 2003; Wade et al., 2004), whereas other researchers have reported no increase in milk production in cows milked more 
frequently by AMS (Speroni et al., 2006; Gygax et al., 2007). Although many factors affect the welfare of dairy cows on a farm, cows milked by AMS can manage their daily activities with more freedom and have more opportunities to interact with their environment (Jacobs and Siegford, 2012). Several researchers have compared the behavioral and physiological stress responses of cows during milking in AMS with those being milked in conventional parlor systems. Cows' heart rates in AMS were similar to or lower than those observed in conventional parlors (Hopster et al., 2002; Wenzel et al., 2003; Weiss et al., 2004; Hagen et al., 2005). Lower maximum plasma adrenaline and noradrenaline concentrations were reported in cows milked in AMS compared with cows milked in conventional parlor systems, which indicates that cows experienced less stress during AMS milking (Hopster et al., 2002). Levels of milk cortisol and fecal corticosteroids did not differ between AMS and conventionally milked cows (Weiss et al., 2004; Gygax et al., 2006; Lexer et al., 2009).

In recent years, buffalo dairy farming in Italy has undergone a marked increase. There are currently about 358,000 head of buffalo on 2,500 farms (ISTAT, 2010), mainly in the center and south of the country (Lazio, Campania, and Apulia). In Italy, buffaloes have been successfully milked by machine for over $30 \mathrm{yr}$, and this was the main means to increase productivity and improve milk quality. However, because cows and buffaloes are similar species, the experience gained and technologies developed for dairy cattle have usually been applied without alteration for buffaloes, even though the anatomy and physiology of the 2 species differ (Caria et al., 2011). Dairy cows store less than 30\% of the total milk yield volume in the udder cistern after a normal milking interval (Ayadi et al., 2003). In dairy buffaloes, only about $5 \%$ of the milk produced between 2 consecutive milkings (10- to 12 -h interval) is stored in the udder cistern, whereas the remaining $95 \%$ of the milk is stored in the alveolar compartment. As a result, premilking stimulation is extremely important for the optimal milk ejection response in buffaloes (Thomas et al., 2004). Moreover, dairy buffaloes have longer and thicker teats compared with dairy cows, which is important to consider when milking buffaloes with a machine (Thomas, 2004). Following the same logic, the automatic milking of dairy buffaloes was introduced for the first time on a commercial farm located in southern Italy (Campania) in 2008. As observed in dairy cows, buffaloes can visit the AMS voluntarily. Consequently, one might expect large variation in the frequency of visits to the milking robot and thus large variations in the milking interval (Hogeveen et al., 2001).

The aims of this study were to evaluate the response of buffaloes to automatic milking and, in particular, the relationships between milking interval, milk production, and milking time for this species.

\section{MATERIALS AND METHODS}

Data were collected during a 3-mo period (December 2010 to February 2011) at a commercial farm with Italian Mediterranean buffaloes in southern Italy (Campania). The farm had 200 dairy buffaloes that were milked automatically in 4 milking stalls (VMS, DeLaval, Tumba, Sweden), each serving 1 pen of buffaloes. Dairy buffaloes were housed in mat-lined freestalls and were fed ad libitum with a TMR provided once a day (0730 to $0900 \mathrm{~h}$ ) and pushed into the feeding trough twice daily. Guided cow traffic was achieved by using a preselection gate controlled by the AMS. The buffaloes that were allowed to be milked could enter the waiting area facing each AMS and then move to the milking box; otherwise, they were rejected and directed to the feeding area. However, during the period of the study, we set no minimum time interval between milkings. Thus, buffaloes could access the robot at any time to be milked. The AMS installed (VMS, DeLaval) used the standard configuration for dairy cows. The only modification was the installation of a steel casing to protect the electronic components inside the milking box from damage by the horns of the animals.

Data collection was limited to VMS1 (1 of the 4 VMS installed in the farm). During the experimental period, the herd managed by VMS1 consisted of, on average, 40 buffaloes, with 228 DIM and 3.18 lactations. The working parameters were $42 \mathrm{kPa}$ vacuum, 60 cycles/ min pulsator rate, and $60 \%$ pulsator ratio. The concentrate feed administered in the milking station to each buffalo ranged between 0.5 and $3.0 \mathrm{~kg} / \mathrm{d}$ based on daily milk yield.

\section{Data Collection}

The following information was collected for each milking, using the VMS herd management software (DeLaval DelPro, DeLaval): buffalo identification number, date and time of buffalo identification, milk yield ( $\mathrm{kg} / \mathrm{milking}$ ), milking duration (time between the buffalo identification and the last teat-cup detachment, min), and milking interval (time between the beginning of 2 consecutive milkings for the same buffalo, h). The average milk flow rate $(\mathrm{kg} / \mathrm{min})$ was calculated as the sum of the milk flow of each quarter.

\section{Data Selection and Analysis}

Before analysis, data were checked for consistency and validity. Data with a milking interval of $<1 \mathrm{~h}$ or 
$>24 \mathrm{~h}$, in accordance with Hogeveen et al. (2001), were discarded, as were data for yields of $<0.5 \mathrm{~kg}$. A total of 7,550 milking records from different buffaloes were used in the present study.

Descriptive statistics (arithmetic average, standard deviation, minimum, and maximum) were calculated for milk yield, milking duration, milking interval, and milk flow rate. The variations in the parameters were also analyzed by evaluating frequency distributions. The variables milk yield, milking duration, milking interval, number of milkings, and average milk flow rate had skewed distributions. Spearman rank correlations $\left(\mathbf{r}_{\mathrm{s}}\right)$ and simple linear regressions were calculated from SPSS software (version 15.0, SPSS Inc., Chicago, IL).

\section{RESULTS AND DISCUSSION}

Table 1 shows the statistical data for the samples in the experiment. The average time interval between consecutive milkings was $10.3 \mathrm{~h}$, greater than that found by de Koning and Ouweltjes (2000) and Hogeveen et al. (2001) for cows $(9.2 \mathrm{~h}$ ), as well as those found in other studies. Jacobs and Siegford (2012), for example, reported in their review article that the most frequent milking interval for cows was between 7 and $8 \mathrm{~h}$. In the current study, a wide distribution in milking frequency was observed. In $71 \%$ of cases, the interval was between 6 and $12 \mathrm{~h}$ (Figure 1), which is very close to the value of $67 \%$ for the time interval reported by Gygax et al. (2007). Only $3.4 \%$ of the milkings occurred after an interval of $\leq 6 \mathrm{~h}$ and $25.7 \%$ occurred after $>12 \mathrm{~h}$. These results are similar to those reported for milking cows (de Koning and Ouweltjes, 2000; Gygax et al., 2007).

Overall, $21.4 \%$ of the buffaloes had a milking frequency $\geq 2.5$ times a day and $3.6 \%$ of had a milking frequency $\leq 2.0$ times/d. A milking frequency of 2.4

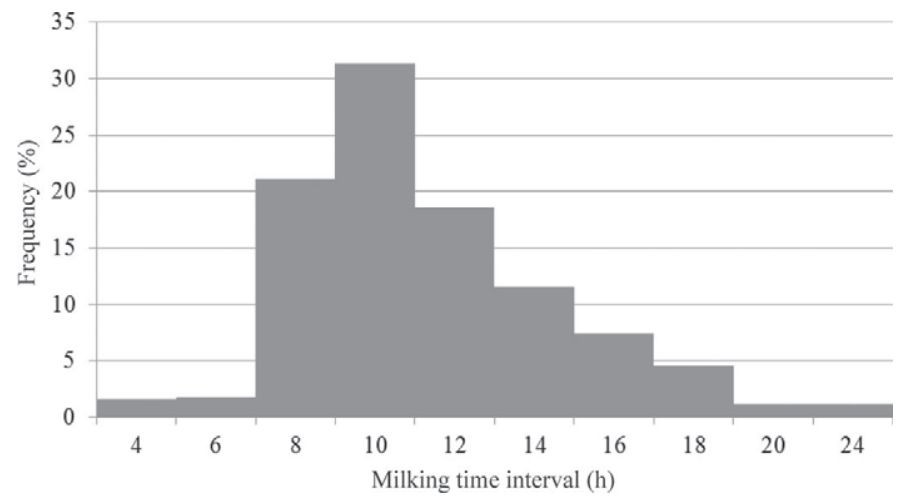

Figure 1. Frequency distribution of all milking intervals (time, in hours, between the beginning of 2 consecutive milkings for the same buffalo) for the herd of buffalo managed by automatic milking system (from December 2010 to February 2011).

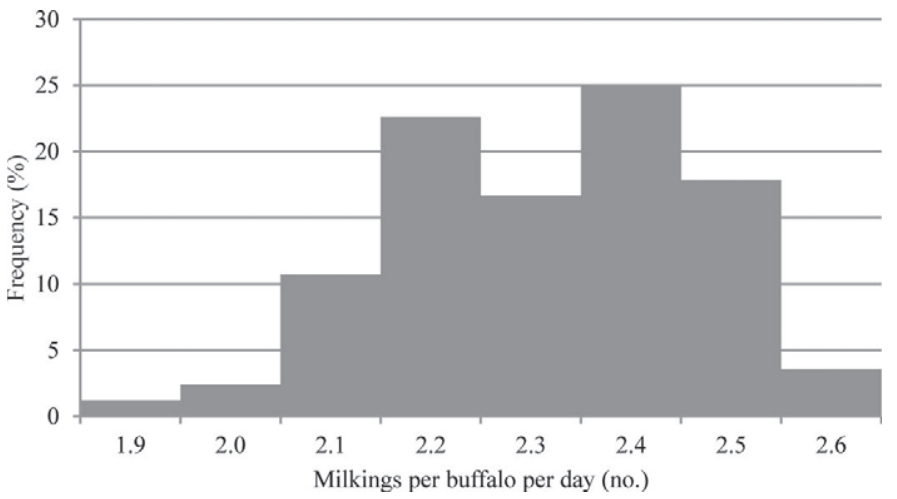

Figure 2. Frequency distribution of average number of milkings per buffalo per day for the herd managed by automatic milking system (from December 2010 to February 2011).

milkings/d was most common (25.0\% of cases), as can be seen in Figure 2. These values are similar to those for milking cows, where the average milking frequency varied between 2.3 and 2.8 (de Koning and Ouweltjes, 2000; Wendl et al., 2000).

In $49.5 \%$ of cases, average milk flow was between 1 and $1.5 \mathrm{~kg} / \mathrm{min}$ (Figure 3). This is very different from the 2.1 to $2.5 \mathrm{~kg} / \mathrm{min}$ found for cows (de Koning and Ouweltjes, 2000). This difference may be because buffalo milk production is lower $(2.8 \pm 1.4 \mathrm{~kg} /$ buffalo per milking) than that of cows $(11.8 \pm 4.3 \mathrm{~kg} /$ cow per milking; de Koning and Ouweltjes, 2000). In addition, morphological differences indicate some peculiarities in milk letdown in buffaloes: the total cistern volume and

Table 1. Descriptive statistics of the data set (herd characteristics, milk yield, milking duration per milking and buffalo, and derived statistics) for the automatic milking of dairy buffaloes during the experimental period (December 2010 to February 2011)

\begin{tabular}{lcc}
\hline Variable & Mean & SD \\
\hline Buffalo per AMS $^{1}$ (no.) & 40 & 5.5 \\
DIM & 228 & 127 \\
Primiparous buffaloes (no.) & 16 & - \\
Primiparous buffaloes (\%) & 30.8 & - \\
Parity (no.) & 3.2 & 2.1 \\
Per milking & 2.8 & 1.4 \\
Milk yield (kg/milking) & 8.3 & 2.7 \\
Milking duration (min/milking) & & \\
Per buffalo & 10.3 & 3.3 \\
Milking interval (h) & 2.3 & 0.2 \\
Milkings (no./buffalo per day) & 6.3 & 0.4 \\
Milk yield (kg/buffalo per day) & 18.6 & 1.4 \\
Duration (min/buffalo per day) & 1.3 & 0.5 \\
Average milk flow rate (kg/min) & & \\
Use of AMS capacity & 89.9 & 10.2 \\
Milkings (no./d) & 12.1 & 1.6 \\
Duration (h/d) & 50.3 & \\
Occupation rate (\%) & 251.0 & 40.2 \\
Milk yield (kg/d) &
\end{tabular}

${ }^{1} \mathrm{AMS}=$ automatic milking system.

${ }^{2}$ Time between buffalo identification and the last teat-cup detachment. 


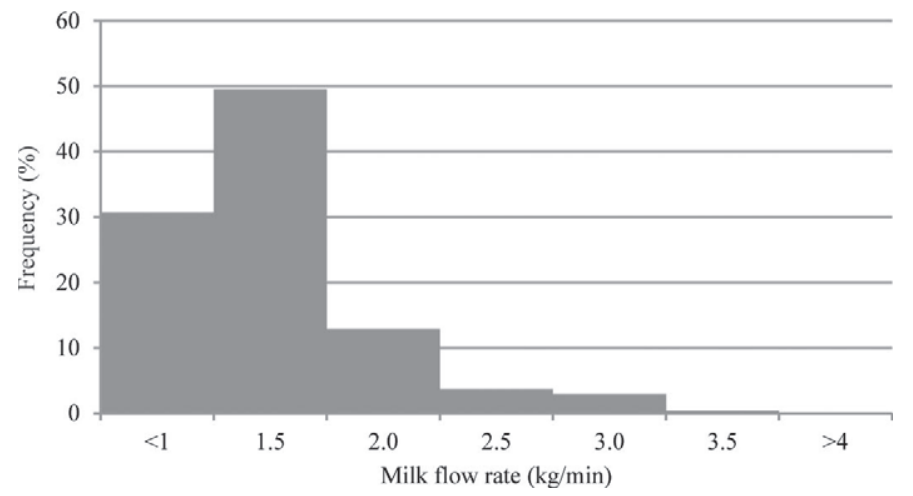

Figure 3. Frequency distribution of average milk flow rates for the herd of buffalo managed by automatic milking system (from December 2010 to February 2011).

milk cisternal fraction in dairy buffaloes are smaller than those in dairy cows. Animals with small cisterns, such as buffaloes, are more susceptible to the shortterm autocrine inhibition of milk secretion, where the presence of milk in large quantities in the secretory tissue leads to reduced milk secretion (Thomas, 2009). In the absence of the milk cisternal fraction, if the milking unit is applied before milk ejection, the teats are exposed to the vacuum that enters the teat canal and milk ducts, causing their collapse. This effect prevents further milk flow, increasing the milking time (Bruckmaier and Blum, 1996; Thomas, 2009). Borghese et al. (2007) reported teat lengths from 6.3 to $8.5 \mathrm{~cm}$ for the Mediterranean Buffalo breed and, according to Thomas et al. (2004), milk ejection causes more than a $10 \%$ increase in teat length and teat girth. Thomas et al. (2004) also found that teat canals were longer in buffaloes $(3.1 \mathrm{~cm})$ than that reported by other researchers for cows (0.5-1.3 cm; Geishauser and Querengässer, 2000; Neijenhuis et al., 2001). Nevertheless, in a recent study, Ambord et al. (2010) observed that a 3-min manual stimulation before teat-cup attachment reduced teat canal length and milk flow occurred between 16 and 38 $\mathrm{kPa}$, whereas, without prestimulation, no milk could be withdrawn with a vacuum up to $39 \mathrm{kPa}$. However, no significant correlation was found between the vacuum required to open the teat canal and teat canal length. Ambord et al. (2010) showed that the tissue above the teat canal provides additional teat closure before milk ejection, falsely increasing the teat canal length. The milk flow results for the second most typical group in our study $(<1 \mathrm{~kg} / \mathrm{min} ; 30.7 \%$ of cases) were similar to those reported for conventional milking of buffaloes by Caria et al. (2011, 2012). They found that, even with different operating vacuum levels, the average flow rate was always $<1 \mathrm{~kg} / \mathrm{min}$. Finally, average flows of between 2.0 and $2.5 \mathrm{~kg} / \mathrm{min}$, which are typical for cows, were only found in $16.6 \%$ of cases in the current study.
The average milking duration was $8.3 \pm 2.7 \mathrm{~min} /$ milking, with a frequency of $47.8 \%$ for values $>6$ and $\leq 9$ min (Figure 4). The high milking duration, substantially greater than that found by André et al. (2010) for cows (5.5 to $6.8 \mathrm{~min}$ ), is probably due to the greater time needed to extract the milk, even though production is lower. Because of their slow milk ejection reflex and thicker sphincter muscle around the streak canal compared with dairy cows, dairy buffaloes are known to be slow and hard to milk: the lag time before milk let-down ranges from 1.6 to $6.3 \mathrm{~min}$ (Costa and Reinemann, 2004; Thomas et al., 2005; Bava et al., 2007; Caria et al., 2011), whereas the lag time from the start of teat stimulation until onset of milk ejection in dairy cows ranges from $40 \mathrm{~s}$ to $>2 \mathrm{~min}$ and increases with a decreasing degree of udder filling (Bruckmaier et al., 1994; Bruckmaier and Hilger, 2001).

Our results confirm those of other studies on buffaloes (Borghese et al., 2007; Caria et al., 2011). Milk yield and average flow rate were positively correlated $\left(\mathrm{r}_{\mathrm{s}}=0.53, P<0.01\right.$; Table 2$)$, even though variations in milk emissions, even in the same animal, mean that milkings generally take a long time because flow rates are low (Caria et al., 2012). In contrast, we observed a weak negative correlation between the above parameters and milking duration. This suggests that the less-productive buffaloes are also those that are most difficult to milk.

We also observed a significant relationship, albeit very weak, between milking duration, the number of lactations $\left(\mathrm{r}_{\mathrm{s}}=0.16, P<0.01\right)$, and DIM $\left(\mathrm{r}_{\mathrm{s}}=-0.12\right.$, $P<0.01$; Table 2). A reduction in total milking time as the stage of lactation increased was also observed in dairy buffaloes milked in conventional milking parlors (Bava et al., 2007). This is probably due to the reduction in cistern size and milk yield as lactation progresses

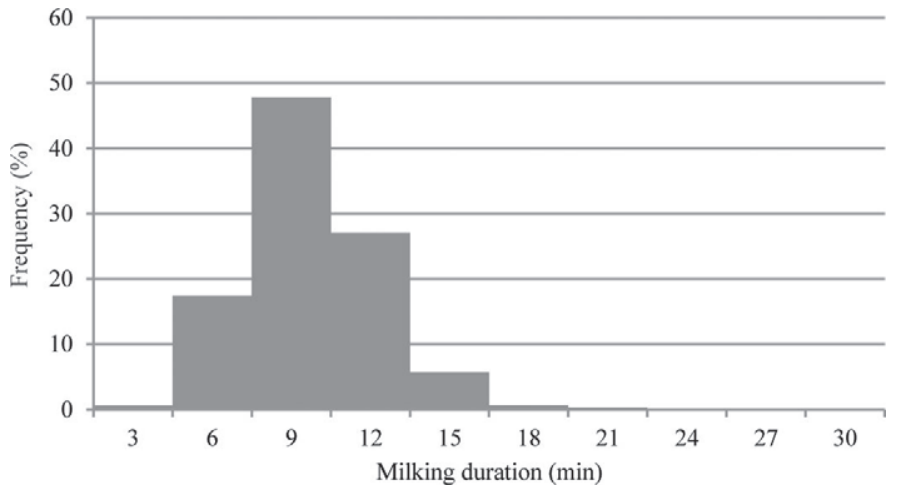

Figure 4. Frequency distribution of milking duration (time between the buffalo identification and the last teat-cup detachment) per buffalo per milking for the herd managed by automatic milking system (from December 2010 to February 2011). 
Table 2. Spearman rank correlations $\left(\mathrm{r}_{\mathrm{s}}\right)$ and statistical significance between variables (total no. of observations per variable $=7,550$ )

\begin{tabular}{|c|c|c|c|c|c|c|}
\hline Item & $\begin{array}{l}\text { Milking } \\
\text { duration }\end{array}$ & $\begin{array}{l}\text { Average } \\
\text { flow rate }\end{array}$ & DIM & $\begin{array}{l}\text { Milking } \\
\text { interval }\end{array}$ & $\begin{array}{l}\text { No. of } \\
\text { lactations }\end{array}$ & Milk yield \\
\hline Milking duration (min) & 1.000 & $-0.34^{* *}$ & $-0.12^{* *}$ & 0.001 & $0.16^{* *}$ & $-0.21^{* *}$ \\
\hline Average flow rate $(\mathrm{kg} / \mathrm{min})$ & & 1.000 & $0.23^{* *}$ & -0.006 & $0.16^{* *}$ & $0.53^{* *}$ \\
\hline Milking interval (h) & & & & 1.000 & $-0.25^{* *}$ & $0.08^{* *}$ \\
\hline No. of lactations & & & & & 1.000 & $0.19^{* *}$ \\
\hline Milk yield (kg) & & & & & & 1.000 \\
\hline
\end{tabular}

**Correlation significant at the 0.01 level.

(Thomas et al., 2004) and to the delay of alveolar milk ejection due to the decrease in udder filling (Bruckmaier and Hilger, 2001). However, no relationship was found between the milking duration and milking interval. This indicates that the average time taken to milk an animal did not influence the daily number of milkings. This result may, however, have been influenced by the number of buffaloes using the AMS station (40 \pm 5.51$)$. The farmer had, indeed, deliberately reduced the number of animals assigned to each AMS station so that all the buffaloes could be milked correctly. We found a very weak relationship between milk yield and milking interval $\left(\mathrm{r}_{\mathrm{s}}=0.08, P<0.01\right)$ but none between milking interval and average milk flow rate, which contrasts with results for cows, where long milking intervals are associated in an increase in milk flow, irrespective of the level of milk production (Hogeveen et al., 2001). Yield per milking and average flow rate were positively correlated with DIM $\left(\mathrm{r}_{\mathrm{s}}=0.10, P<0.001 ; \mathrm{r}_{\mathrm{s}}=0.23, P<\right.$
0.001; Table 2) and the number of milkings $\left(\mathrm{r}_{\mathrm{s}}=0.19\right.$, $\left.P<0.001 ; \mathrm{r}_{\mathrm{s}}=0.16, P<0.001\right)$. We found a negative relationship between milking interval, the number of milkings $\left(\mathrm{r}_{\mathrm{s}}=-0.25, P<0.001\right)$, and DIM $\left(\mathrm{r}_{\mathrm{s}}=0.20\right.$, $P<0.001$ ), as is also the case for cows (Dzidic et al., 2004; Jacobs and Siegford, 2012).

Our results showed a good coefficient of determination for the 3 linear regressions calculated here (Figures 5, 6, and 7 ). The daily yield determined the amount of time that the AMS was used daily $\left(\mathrm{R}^{2}=0.83, P<0.001\right)$.

Increasing the daily yield per station was conditioned by the number of times per day that buffaloes used an AMS station $\left(\mathrm{R}^{2}=0.87, P<0.001\right)$, as has been reported in many studies on cows (de Koning et al., 2002; Wagner-Storch and Palmer, 2003; Wade et al., 2004; Melin et al., 2005). The increase in the number of daily visits to the AMS was significantly correlated with the number of animals per AMS station $\left(\mathrm{R}^{2}=\right.$ $0.72, P<0.001)$.

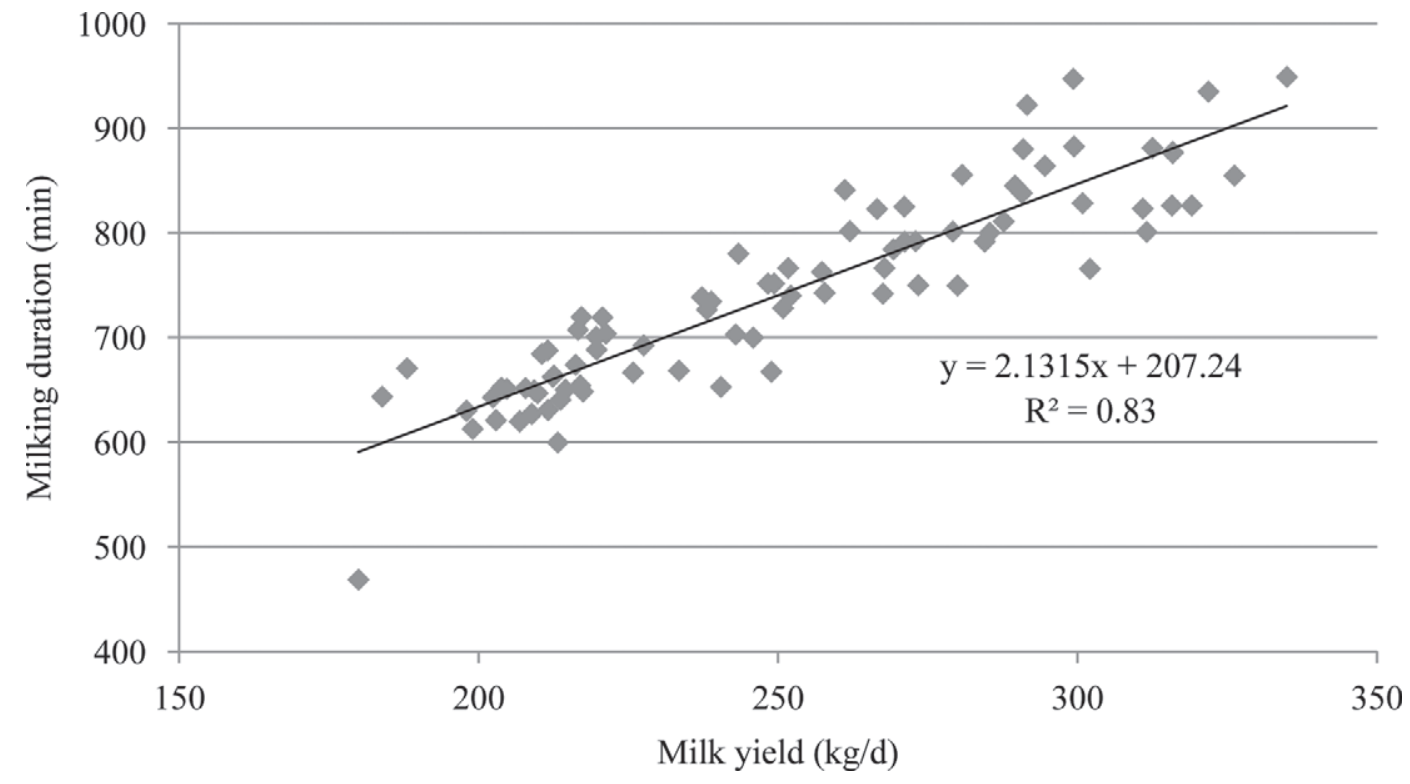

Figure 5. Relationship between milk yield per day from all the dairy buffaloes milked in an automatic milking system and milking duration (time between buffalo identification and the last teat-cup detachment) per day $(P<0.001)$. 


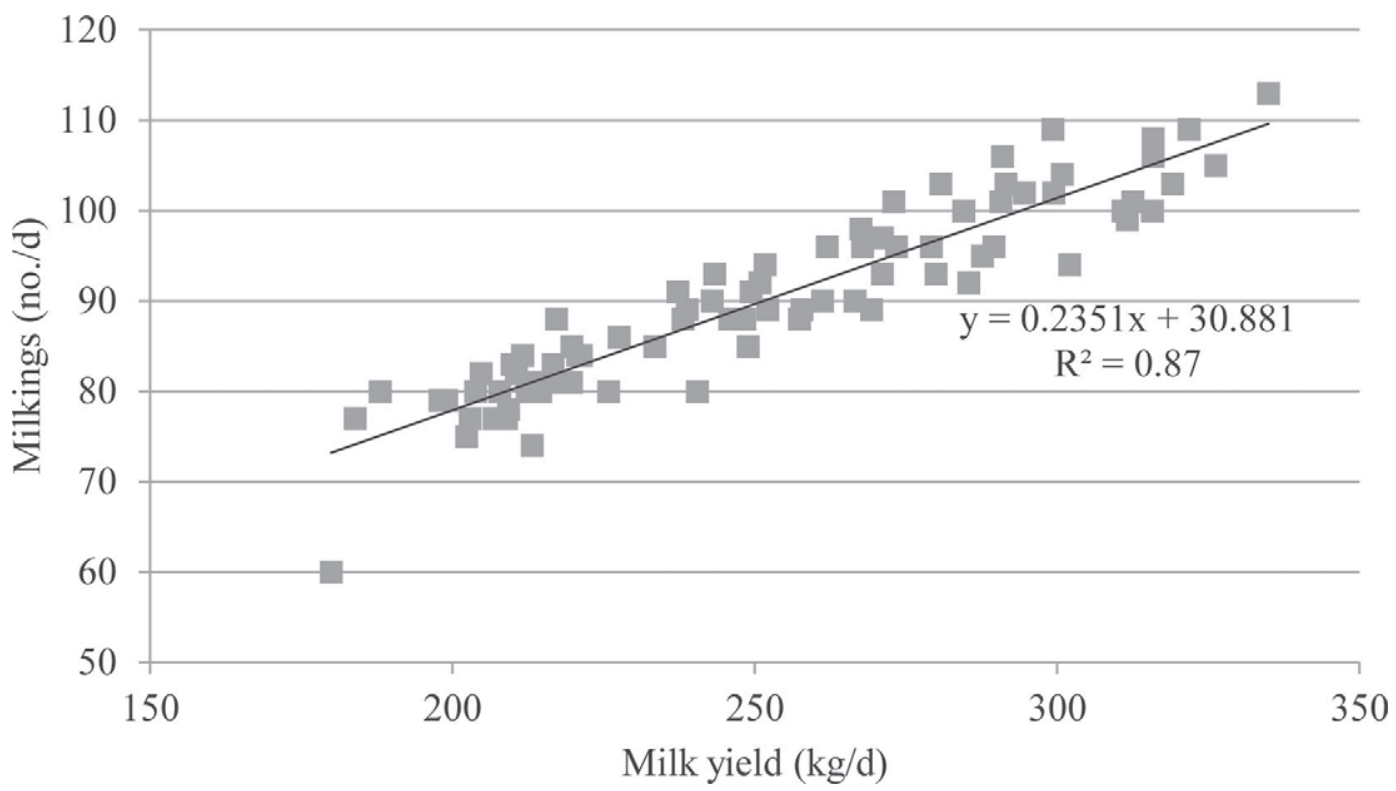

Figure 6. Relationship between milkings per day and milk yield per day for the herd of buffalo managed by automatic milking system $(P$ $<0.001)$.

\section{Number of Milkings per Day and Daily Production}

The results were used to calculate the maximum number of milkings per day and the optimal number of buffaloes per AMS for a determined level of milk production. This was done using the average milking duration per milking for each production level (from
2 to $5 \mathrm{~kg} /$ milking) and with the milking station being occupied for $80 \%$ of the time (Table 3) (Rossing et al., 1997; de Koning and Ouweltjes, 2000).

To calculate the potential number of milkings per day, the occupation rate was multiplied by $1,440 /$ milking duration per visit, where the occupation rate is the percentage of $24 \mathrm{~h}$ that the AMS is used for milking

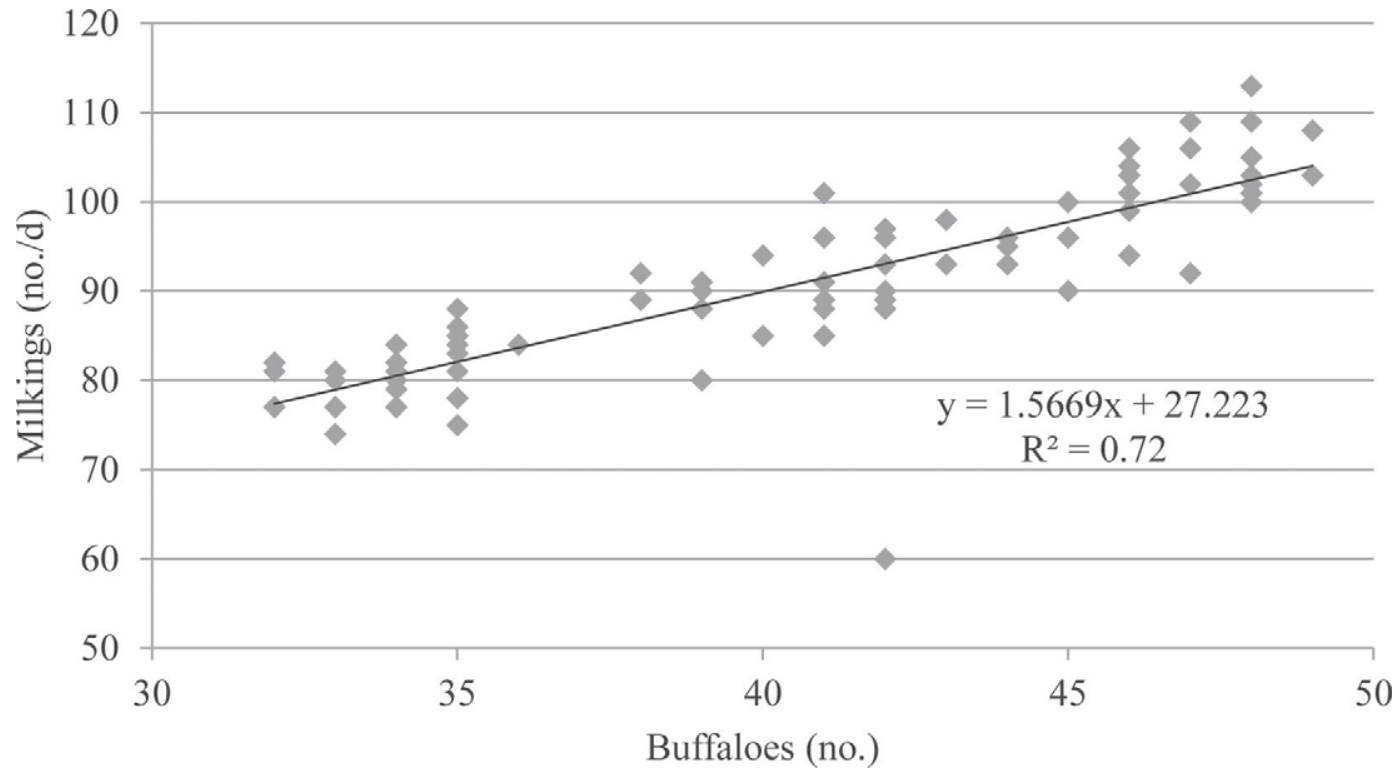

Figure 7. Relationship between number of buffaloes in the automatic milking system and milkings per day for the herd of buffalo managed by automatic milking system $(P<0.001)$. 
Table 3. Flow rate, milking duration, number of milkings per day, number of buffaloes per automatic milking system (AMS), and milk yield $(\mathrm{kg} / \mathrm{d})$ at an occupation rate of $80 \%$

\begin{tabular}{lcccc}
\hline & \multicolumn{4}{c}{ Yield $(\mathrm{kg} / \mathrm{milking})$} \\
\cline { 2 - 5 } Item & 2 & 3 & 4 & 5 \\
\hline Flow rate $(\mathrm{kg} / \mathrm{min})$ & 1.10 & 1.28 & 1.50 & 1.72 \\
Milking duration (min) & 8.48 & 7.93 & 7.56 & 7.62 \\
Milk yield (kg/d) & 271.8 & 435.9 & 609.6 & 756.0 \\
No. of milkings per day & 136 & 145 & 152 & 151 \\
No. of buffaloes per AMS & 59 & 63 & 66 & 66 \\
\hline
\end{tabular}

and the milking duration per visit is the time between the identification of the buffalo and the removal of the last teat cup.

When the average production of the buffaloes was $2 \mathrm{~kg} /$ milking, the maximum number of milkings per AMS station was 136 per day (Table 3), whereas when average production was $4 \mathrm{~kg} /$ milking, the number of milkings increased to 152 per day (an increase of $12 \%$ ). This result is different from the results estimated for cows by de Koning and Ouweltjes (2000). They found that increased yield also increased the total time spent at the milking station, with a resulting decrease in the number of daily milkings. The lower number of daily milkings with low-yield buffaloes may be due to the major lag time before milk ejection (period between teat-cup attachment and the start of milk ejection) for the latter. The lag time tends to increase as the stage of lactation increases (Bava et al., 2007), when both milk yield and cistern size are reduced (Thomas et al., 2004).

However, milkings with an average yield of $2 \mathrm{~kg}$ mean that the daily milk production per milking station is modest $(271.8 \mathrm{~kg} / \mathrm{d})$. If the average yield per milking were doubled to $4 \mathrm{~kg}$, then total milk production would increase to $609.6 \mathrm{~kg} / \mathrm{d}$ (an increase of $337.8 \mathrm{~kg} / \mathrm{d}$ ).

The results we obtained may be useful for estimating the maximum number of buffaloes per AMS station. In Table 3, the maximum number of milkings per day (152) was divided by the average milkings per buffalo per day to calculate the number of buffaloes per AMS station at an $80 \%$ occupation rate. Thus, if the average number of milkings per buffalo per day is 2.3 (from the average values obtained in this work), then the maximum number of buffaloes that can be milked by the AMS station is 66 .

In regard to the economics of an AMS, it is possible to compare the milk revenue of buffalo and cow AMS because the operating costs of the equipment are the same. With a yield of $435.9 \mathrm{~kg}$ of milk/d per AMS at an $80 \%$ occupation rate (Table 3 ) and a buffalo milk price of $€ 1.23 / \mathrm{L}$ (ISMEA, 2007), milk revenue would be $€ 536 /$ d. André et al. (2010), at the same occupation rate $(80 \%)$ and considering optimal individual intervals for the animals, obtained $€ 525 / \mathrm{d}$ of milk revenue per
AMS in cows. Thus, the pay back [the length of time required to recover the investment (payback period $=$ cost of investment/annual cash inflows)] of AMS does not differ much between buffaloes and cows. As for dairy cows, the choice to adopt an AMS in buffalo farms must consider not only economic aspects, but also the adaptability of the herd.

\section{CONCLUSIONS}

Voluntary AMS are suitable for dairy buffaloes. The frequency distribution of milking intervals and average milking frequency were similar to those reported for milking cows. As expected, milk yield and flow rate were lower and milking time longer compared with those for dairy cows. Nonetheless, our results are comparable with the results for buffaloes milked using conventional systems. Thus, AMS may be a promising alternative to conventional mechanical milking for buffaloes, opening new options for the management of dairy buffalo farms.

\section{REFERENCES}

Ambord, S., M. H. Stoffel, and R. M. Bruckmaier. 2010. Teat anatomy affects requirements for udder preparation in Mediterranean buffaloes. J. Dairy Res. 77:468-473.

André, G., P. B. M. Berentsen, B. Engel, C. J. A. M. de Koning, and A. G. J. M. Oude Lansink. 2010. Increasing the revenues from automatic milking by using individual variation in milking characteristics. J. Dairy Sci. 93:942-953.

Ayadi, M., G. Caja, X. Such, and C. H. Knight. 2003. Use of ultrasonography to estimate cistern size and milk storage at different milking intervals in the udder of dairy cows. J. Dairy Res. 70:1-7.

Bava, L., A. Sandrucci, A. Tamburini, and M. Zucali. 2007. Milk flow traits of buffalo cows in intensive farming system. Ital. J. Anim. Sci. 6:500-502.

Borghese, A., M. Rasmussen, and C. S. Thomas. 2007. Milking management of dairy buffaloes. Ital. J. Anim. Sci. 6:39-50.

Bruckmaier, R. M., and J. W. Blum. 1996. Simultaneous recording of oxytocin release, milk ejection and milk flow during milking of dairy cows with and without prestimulation. J. Dairy Res. 63:201-208.

Bruckmaier, R. M., and M. Hilger. 2001. Milk ejection in dairy cows at different degrees of udder filling. J. Dairy Res. 68:369-376.

Bruckmaier, R. M., D. Schams, and J. W. Blum. 1994. Continuously elevated concentrations of oxytocin during milking are necessary for complete milk removal in dairy cows. J. Dairy Res. 61:323334.

Caria, M., C. Boselli, L. Murgia, R. Rosati, and A. Pazzona. 2012. Effect of vacuum level on milk flow traits in Mediterranean Italian buffalo cow. Ital. J. Anim. Sci. 11:137-139. 
Caria, M., L. Murgia, and A. Pazzona. 2011. Effects of the working vacuum level on mechanical milking of buffalo. J. Dairy Sci. 94:1755-1761.

Costa, D. A., and D. J. Reinemann. 2004. The purpose of the milking routine and comparative physiology of milk removal. Pages 189-197 in Proc. Natl. Mastitis Council Annu. Mtg., Charlotte, NC. National Mastitis Counc., Verona, WI.

de Koning, K. 2010. Automatic milking - Common practice on dairy farms. Pages V59-V63 in Proc. Second North Am. Conf. Robotic Milking, Toronto, Canada. Precision Dairy Operators, Elora, ON, Canada.

de Koning, K., and W. Ouweltjes. 2000. Maximising the milking capacity of an automatic milking system. Pages 38-46 in Proc. Int. Symp. Robotic Milking, Lelystad, the Netherlands. Wageningen Academic Publishers, Wageningen, the Netherlands.

de Koning, K., and J. Rodenburg. 2004. Automatic milking: State of the art in Europe and North America. Pages 27-35 in Automatic Milking: A Better Understanding. A. Meijering, H. Hogeveen, and C. J. A. M. de Koning, ed. Wageningen Academic Publishers, Wageningen, the Netherlands.

de Koning, K., Y. van der Vost, and A. Meijering. 2002. Automatic milking experience and development in Europe. Pages I1-I11 in Proc. First North Am. Conf. Robotic Milking, Toronto, Canada. Wageningen Academic Publishers, Wageningen, the Netherlands.

Dzidic, A., D. Weiss, and R. M. Bruckmaier. 2004. Oxytocin release, milk ejection and milking characteristics in a single stall automatic milking system. Livest. Prod. Sci. 86:61-68.

Geishauser, T., and K. Querengässer. 2000. Investigation on teat canal lengths in teats with milk flow disturbances. J. Dairy Sci. 38:1976-1980.

Gygax, L., I. Neuffer, C. Kaufmann, R. Hauser, and B. Wechsler. 2006. Milk cortisol concentration in automatic milking systems compared with auto-tandem milking parlors. J. Dairy Sci. 89:3447-3454.

Gygax, L., I. Neuffer, C. Kaufmann, R. Hauser, and B. Wechsler. 2007. Comparison of functional aspects in two automatic milking systems and auto-tandem milking parlors. J. Dairy Sci. 90:42654274 .

Hagen, K., J. Langbein, C. Schmied, D. Lexer, and S. Waiblinger 2005. Heart rate variability in dairy cows - Influences of breed and milking system. Physiol. Behav. 85:195-204.

Hogeveen, H., W. Ouweltjes, C. J. A. M. de Koning, and K. Stelwagen. 2001. Milking interval, milk production and milk flowrate in an automatic milking system. Livest. Prod. Sci. 72:157-167.

Hopster, H., R. M. Bruckmaier, J. T. N. Van der Werf, S. M. Korte, J. Macuhova, G. Korte-Bouws, and G. van Reenen. 2002. Stress responses during milking: Comparing conventional and automatic milking in primiparous dairy cows. J. Dairy Sci. 85:3206-3216.

ISMEA. 2007. Istituto di servizi per il mercato agricolo alimentare (ISMEA) - Analisi del costo e della redditività della produzione di latte di bufala - Indagine 2007. Accessed Dec. 26, 2013. http:// www.ismea.it/flex/cm/pages/ServeBLOB.php/L/IT/IDPagina/ 2855.

ISTAT. 2010. Istituto nazionale di statistica (ISTAT) - $6^{\circ}$ General census of agriculture (provisional data). Accessed Dec. 26, 2013. http://dati-censimentoagricoltura.istat.it/.

Jacobs, J. A., and J. M. Siegford. 2012. Invited review: The impact of automatic milking systems on dairy cow management, behavior, health, and welfare. J. Dairy Sci. 95:2227-2247.

Lexer, D., K. Hagen, R. Palme, J. Troxler, and S. Weiblinger. 2009. Time budgets and adrenocortical activity of cows milked in a robot or a milking parlour: Interrelationships and influence of social rank. Anim. Welf. 18:73-80.
Melin, M., K. Svennersten-Sjaunja, and H. Wiktorsson. 2005. Feeding patterns and performance of cows controlled cow traffic in automatic milking systems. J. Dairy Sci. 88:3913-3922.

Neijenhuis, F., G. H. Klungel, and H. Hogeveen. 2001. Recovery of cow teats after milking as determined by ultrasonographic scanning. J. Dairy Sci. 84:2599-2606.

Rossing, W., P. H. Hogewerf, A. H. Ipema, C. C. Ketelaar De Lauwere, and C. J. A. M. deKoing. 1997. Robotic milking in dairy farming. Neth. J. Agric. Sci. 45:15-31.

Rotz, C. A., C. U. Coiner, and K. J. Soder. 2003. Automatic milking systems, farm size, and milk production. J. Dairy Sci. 86:41674177

Speroni, M., G. Pirlo, and S. Lolli. 2006. Effect of automatic milking systems on milk yield in a hot environment. J. Dairy Sci. 89:4687-4693.

Stelwagen, K., C. V. Phyn, S. R. Davis, J. Guinard-Flament, D. Pomiès, J. R. Roche, and J. K. Kay. 2013. Invited review: Reduced milking frequency: Milk production and management implications. J. Dairy Sci. 96:3401-3413.

Svennersten-Sjaunja, K. M., and G. Pettersson. 2008. Pros and cons of automatic milking in Europe. J. Anim. Sci. 86:37-46.

Thomas, C. S. 2004. Milking management of dairy buffaloes. PhD Thesis. Department of Animal Nutrition and Management, Swedish University of Agricultural Sciences, Uppsala, Sweden.

Thomas, C. S. 2009. Housing and management of lactating buffaloes Pages 11-26 (CD-ROM) in Proc. Europe and America's Buffalo Symp., Pedro Leopoldo, Brazil. Colégio Brasileiro de Reprodução Animal (CBRA), Belo Horizonte, Brazil.

Thomas, C. S., R. M. Bruckmaier, K. Ostensson, and K. SvennerstenSjaunja. 2005. Effect of different milking routines on milking-related release of the hormones oxytocin, prolactin and cortisol, and on milk yield and milking performance in Murrah buffaloes. J. Dairy Res. 72:10-18.

Thomas, C. S., K. Svennersten-Sjaunja, M. R. Bhosrekar, and R. M. Bruckmaier. 2004. Mammary cisternal size, cisternal milk and milk ejection in Murrah buffaloes. J. Dairy Res. 71:162-168.

Wade, K. M., M. A. P. M. van Asseldonk, P. B. M. Berentsen, W. Ouweltjes, and H. Hogeveen. 2004. Economic efficiency of automatic milking systems with specific emphasis on increases in milk production. Pages 62-67 in Automatic Milking: A Better Understanding. A. Meijering, H. Hogeveen, and C. J. A. M. de Koning, ed Wageningen Academic Publishers, Wageningen, the Netherlands.

Wagner-Storch, A. M., and R. W. Palmer. 2003. Feeding behavior, milking behavior, and milk yields of cows milked in a parlor versus automatic milking system. J. Dairy Sci. 86:1494-1502.

Weiss, D., S. Helmreich, E. Möstl, A. Dzidic, and R. M. Bruckmaier. 2004. Coping capacity of dairy cows during the change from conventional to automatic milking. J. Anim. Sci. 82:563-570.

Wendl, G., J. Harms, and H. Schön. 2000. Analysis of milking behavior on automatic milking. Pages 143-151 in Proc. Int. Symp. Robotic Milking, Lelystad, the Netherlands. H. Hogeveen and A. Meijering, ed. Wageningen Academic Publishers, Wageningen, the Netherlands.

Wenzel, C., S. Schönreiter-Fischer, and J. Unshelm. 2003. Studies on step-kick behavior and stress of cows during milking in an automatic milking system. Livest. Prod. Sci. 83:237-246.

Wright, J. B., E. H. Wall, and T. B. McFadden. 2013. Effects of increased milking frequency during early lactation on milk yield and udder health of primiparous Holstein heifers. J. Anim. Sci. 91:195-202. 